Скопје, Македонија

\title{
IDENTITIES OF SONIN-TYPE AND APPLICATIONS
}

\author{
ANDREA AGLIĆ ALJINOVIĆ, JOSIP PEČARIĆ, \\ AND SANJA TIPURIĆ-SPUŽEVIĆ
}

\begin{abstract}
Some weighted generalizations of recently obtained identities for perturbed Čebyšev functionals are given by using Sonin's identity. They are used to obtain the new bounds for perturbed weighted Čbyšev functionals. In a special cases they are reduced to Grüss type inequalities.
\end{abstract}

\section{INTRODUCTION}

For two Lebesgue integrable functions $f, g:[a, b] \rightarrow \mathbb{R}$, Čebyšev functional is given by

$T(f, g)=\frac{1}{b-a} \int_{a}^{b} f(x) g(x) d x-\frac{1}{(b-a)^{2}}\left(\int_{a}^{b} f(x) d x\right)\left(\int_{a}^{b} g(x) d x\right)$.

In 1882, Čebyšev in [1] proved that

$$
|T(f, g)| \leq \frac{1}{12}\left\|f^{\prime}\right\|_{\infty}\left\|g^{\prime}\right\|_{\infty}(b-a)^{2},
$$

where $f, g:[a, b] \rightarrow \mathbb{R}$ are such that $f^{\prime}, g^{\prime}$ exists and are continuous on $[a, b]$ and $\left\|f^{\prime}\right\|_{\infty}=\sup _{t \in[a, b]}\left|f^{\prime}(t)\right|$. It also holds if $f, g:[a, b] \rightarrow \mathbb{R}$ are absolutely continuous and $f^{\prime}, g^{\prime} \in L_{\infty}[a, b]$ while $\left\|f^{\prime}\right\|_{\infty}=e s s \sup _{t \in[a, b]}|f(t)|$.

In 1934, Grüss in his paper [3] proved that

$$
|T(f, g)| \leq \frac{1}{4}(M-m)(N-n),
$$

provided that there exists the real numbers $m, M, n, N$ such that

$$
m \leq f(t) \leq M, \quad n \leq g(t) \leq N
$$

for a.e. $t \in[a, b]$. The constant $1 / 4$ is the best possible.

2000 Mathematics Subject Classification. 26D15, 26D20, 26 D99.

Key words and phrases. Sonin's identity, perturbed weighted Čebyšev functional. 
6 ANDREA AGLIĆ ALJINOVIĆ, JOSIP PEČARIĆ, AND SANJA TIPURIĆ-SPUŽEVIĆ

S. S. Dragomir in the recent paper [2] established two representations of Cebyšev functional $T(f, g)$. First if $f$ is absolutely continuous on $[a, b]$ and $g$ Lebesgue integrable on $[a, b]$ then

$$
T(f, g)=\frac{1}{(b-a)} \int_{a}^{b} \int_{a}^{b} P(x, t)(g(x)-\lambda) f^{\prime}(t) d x d t
$$

where $\lambda$ is arbitrary real number and the Peano kernel $P(x, t)$ is defined by

$$
P(x, t)=\left\{\begin{array}{cc}
\frac{1}{b-a}(t-a), & a \leq t \leq x, \\
\frac{1}{b-a}(t-b) & x<t \leq b,
\end{array}\right.
$$

and second, if $f$ and $g$ are absolutely continuous on $[a, b]$ then

$$
T(f, g)=\int_{a}^{b} \int_{a}^{b} K(x, t) f^{\prime}(t) g^{\prime}(x) d x d t
$$

where

$$
K(x, t)= \begin{cases}\frac{1}{(b-a)^{2}}(t-a)(b-x), & a \leq t \leq x \\ \frac{1}{(b-a)^{2}}(b-t)(x-a) & x<t \leq b\end{cases}
$$

With the following notation for Lebesgue norm

$$
\|f\|_{\infty}=e s s \sup _{t \in[a, b]}|f(t)|, \quad\|f\|_{p}=\left(\int_{a}^{b}|f(t)|^{p} d t\right)^{\frac{1}{p}}, 1 \leq p<\infty,
$$

identities (1) and (2) were used in the same paper [2] to obtain the bounds of the perturbed Cebyšev functionals $T(f, g)-\mu T(e, g)$ and $T(f, g)-$ $\mu T(e, g)-\nu T(f, e)$ when $\mu, \nu \in \mathbb{R}$ and $e(t)=t, t \in[a, b]$, which are given in next two theorems.

Theorem 1. Assume that $g:[a, b] \rightarrow \mathbb{R}$ is Lebesgue integrable function on $[a, b]$ and $f:[a, b] \rightarrow \mathbb{R}$ is absolutely continuous on $[a, b], p, q>1$ such that $1 / p+1 / q=1$, then for any $\mu \in \mathbb{R}$

$$
\begin{aligned}
& |T(f, g)-\mu T(e, g)| \\
& \leq\left\{\begin{array}{cc}
\frac{1}{3}(b-a)\left\|f^{\prime}-\mu\right\|_{\infty} \inf _{\gamma \in \mathbb{R}}\|g-\gamma\|_{\infty}, & \text { if } f^{\prime}, g \in L_{\infty}[a, b] \\
\left(\frac{2}{(q+1)(q+2)}\right)^{\frac{1}{q}}(b-a)^{\frac{p-q}{p q}}\left\|f^{\prime}-\mu\right\|_{p} \inf _{\gamma \in \mathbb{R}}\|g-\gamma\|_{p}, & \text { if } f^{\prime}, g \in L_{p}[a, b] \\
(b-a)^{-1}\left\|f^{\prime}-\mu\right\|_{1} \inf _{\gamma \in \mathbb{R}}\|g-\gamma\|_{1} . &
\end{array}\right.
\end{aligned}
$$


Theorem 2. Assume that $f, g:[a, b] \rightarrow \mathbb{R}$ are absolutely continuous on $[a, b], p, q>1$ such that $1 / p+1 / q=1$, then for any $\mu, \nu \in \mathbb{R}$

$$
\begin{aligned}
& |T(f, g)-\mu T(e, g)-\nu T(f, e)| \\
& \leq\left\{\begin{array}{cc}
\frac{1}{12}(b-a)^{2}\left\|f^{\prime}-\mu\right\|_{\infty}\left\|g^{\prime}-\nu\right\|_{\infty}, & \text { if } f^{\prime}, g \in L_{\infty}[a, b] \\
{\left[\frac{B(q+1, q+1)}{q+1}\right]^{\frac{1}{q}}(b-a)^{\frac{2}{q}}\left\|f^{\prime}-\mu\right\|_{p}\left\|g^{\prime}-\nu\right\|_{p},} & \text { if } f^{\prime}, g \in L_{p}[a, b] \\
\frac{1}{4}\left\|f^{\prime}-\mu\right\|_{1}\left\|g^{\prime}-\nu\right\|_{1} . &
\end{array}\right.
\end{aligned}
$$

The aim of this paper is to give weighted generalizations of identities (1) and (2). By using these identities we will also give weighted generalizations of the Theorem 1 and Theorem 2, i.e. bounds for perturbed weighted Čebyšev functionals

$$
T_{w}(f-\mu e, g), \quad T_{w}(f-\mu e, g-\nu e),
$$

when $\mu, \nu \in \mathbb{R}$ and $e(t)=t, t \in[a, b]$ and weighted Čebyšev functional is given by

$T_{w}(f, g)=\int_{a}^{b} w(x) f(x) g(x) d x-\left(\int_{a}^{b} w(x) f(x) d x\right)\left(\int_{a}^{b} w(x) g(x) d x\right)$

where $f, g:[a, b] \rightarrow \mathbb{R}$ are two Lebesgue integrable functions and $w:$ $[a, b] \rightarrow[0, \infty\rangle$ is some normalized weight function.

\section{Representation Results for PERTURBed Weighted ČEByŠEV FUNCTIONAL}

In the next lemma the first representation for weighted Čebyšev functional $T_{w}(f, g)$ is given. The method of proof is different and simpler from that of the identity (1) in [2]. Here, we use the Sonin identity.

Lemma 1. If $f:[a, b] \rightarrow \mathbb{R}$ is absolutely continuous on $[a, b]$ and $g:[a, b] \rightarrow$ $\mathbb{R}$ is Lebesgue integrable function on $[a, b], w:[a, b] \rightarrow[0, \infty\rangle$ is some Lebesgue integrable normalized weight function and $W(t)=\int_{a}^{t} w(x) d x$ for $t \in[a, b]$, then

$$
T_{w}(f, g)=\int_{a}^{b} \int_{a}^{b} w(x) P_{w}(x, t)(g(x)-\lambda) f^{\prime}(t) d x d t
$$


8 ANDREA AGLIĆ ALJINOVIĆ, JOSIP PEČARIĆ, AND SANJA TIPURIĆ-SPUŽEVIĆ

for any $\lambda \in \mathbb{R}$, where the weighted Peano kernel is

$$
P_{w}(x, t)=\left\{\begin{array}{cc}
W(t), & a \leq t \leq x, \\
W(t)-1 & x<t \leq b .
\end{array}\right.
$$

Proof. We apply Sonin's identity (see [7])

$$
T_{w}(f, g)=\int_{a}^{b} w(x)(g(x)-\lambda)\left(f(x)-\int_{a}^{b} w(x) f(x) d x\right) d x
$$

where $\lambda$ is arbitrary real number, with weighted Montgomery identity for function $f$ (obtained by J. Pečarić in [5]) which states

$$
f(x)=\int_{a}^{b} w(t) f(t) d t+\int_{a}^{b} P_{w}(x, t) f^{\prime}(t) d t .
$$

Thus we have

$$
\begin{aligned}
T_{w}(f, g) & =\int_{a}^{b} w(x)(g(x)-\lambda)\left(\int_{a}^{b} P_{w}(x, t) f^{\prime}(t) d t\right) d x \\
& =\int_{a}^{b} \int_{a}^{b} w(x) P_{w}(x, t)(g(x)-\lambda) f^{\prime}(t) d x d t .
\end{aligned}
$$

Now, we can state the following integral representation for perturbed weighted Čebyšev functional $T_{w}(f-\mu e, g)$ when $\mu \in \mathbb{R}$ and $e(t)=t$, $t \in[a, b]$.

Theorem 3. Suppose that all assumptions of Lemma 1 hold. If e $:[a, b] \rightarrow$ $\mathbb{R}, e(t)=t$, we have

$$
T_{w}(f, g)=\mu T_{w}(e, g)+\int_{a}^{b} \int_{a}^{b} w(x) P_{w}(x, t)(g(x)-\lambda)\left(f^{\prime}(t)-\mu\right) d x d t
$$

for any $\lambda, \mu \in \mathbb{R}$.

Proof. By using the Lemma 1 and utilizing the linearity property of $T_{w}(f, g)$ in each argument, the proof follows.

Remark 1. For the uniform normalized weight function $w(t)=\frac{1}{b-a}$, $t \in[a, b]$, the weighted Peano kernel $P_{w}(x, t)$ reduces to the Peano kernel $P(x, t)$ defined by

$$
P(x, t)=\left\{\begin{array}{cc}
\frac{1}{b-a}(t-a), & a \leq t \leq x \\
\frac{1}{b-a}(t-b) & x<t \leq b .
\end{array}\right.
$$


Consequently, for the uniform normalized weight function the results from Lemma 1 and Theorem 3 reduce to the results from [2], that is (1) from the introduction and

$$
T(f, g)=\mu T(e, g)+\frac{1}{b-a} \int_{a}^{b} \int_{a}^{b} P(x, t)(g(x)-\lambda)\left(f^{\prime}(t)-\mu\right) d x d t
$$

where

$$
T(e, g)=\frac{1}{b-a} \int_{a}^{b} g(t) t d t-\frac{a+b}{2(b-a)} \int_{a}^{b} g(t) d t .
$$

In the next lemma we derive the second representation for weighted Čebyšev functional $T_{w}(f, g)$.

Lemma 2. If $f:[a, b] \rightarrow \mathbb{R}$ and $g:[a, b] \rightarrow \mathbb{R}$ are absolutely continuous on $[a, b], w:[a, b] \rightarrow[0, \infty\rangle$ is some Lebesgue integrable normalized weight function and $W(t)=\int_{a}^{t} w(x) d x$ for $t \in[a, b]$, then

$$
T_{w}(f, g)=\int_{a}^{b} \int_{a}^{b} K_{w}(x, t) f^{\prime}(t) g^{\prime}(x) d x d t
$$

where

$$
K_{w}(x, t)= \begin{cases}W(t)(1-W(x)), & a \leq t \leq x, \\ (1-W(t)) W(x) & x<t \leq b .\end{cases}
$$

Proof. By the Fubini's theorem and identity (3) we have

$$
\begin{aligned}
T_{w}(f, g) & =\int_{a}^{b} \int_{a}^{b} w(x) P_{w}(x, t)(g(x)-\lambda) f^{\prime}(t) d x d t \\
& =\int_{a}^{b}\left(\int_{a}^{b} w(x) P_{w}(x, t)(g(x)-\lambda) d x\right) f^{\prime}(t) d t .
\end{aligned}
$$

Integrating by parts and using the fact that $W(a)=0$ and $W(b)=1$ we obtain

$$
\begin{aligned}
& \int_{a}^{b} w(x) P_{w}(x, t)(g(x)-\lambda) d x \\
& =(W(t)-1) \int_{a}^{t} w(x)(g(x)-\lambda) d x+W(t) \int_{t}^{b} w(x)(g(x)-\lambda) d x \\
& =(W(t)-1)\left(W(t)(g(t)-\lambda)-\int_{a}^{t} W(x) g^{\prime}(x) d x\right) \\
& +W(t)\left((g(b)-\lambda)-W(t)(g(t)-\lambda)-\int_{t}^{b} W(x) g^{\prime}(x) d x\right)
\end{aligned}
$$


10 ANDREA AGLIĆ ALJINOVIĆ, JOSIP PEČARIĆ, AND SANJA TIPURIĆ-SPUŽEVIĆ

$$
\begin{aligned}
& =W(t)(-g(t)+g(b))+(1-W(t)) \int_{a}^{t} W(x) g^{\prime}(x) d x-W(t) \int_{t}^{b} W(x) g^{\prime}(x) d x \\
& =\int_{a}^{t}(1-W(t)) W(x) g^{\prime}(x) d x+\int_{t}^{b} W(t)(1-W(x)) g^{\prime}(x) d x \\
& =\int_{a}^{b} K_{w}(x, t) g^{\prime}(x) d x
\end{aligned}
$$

and thus we have

$$
T_{w}(f, g)=\int_{a}^{b}\left(\int_{a}^{b} K_{w}(x, t) g^{\prime}(x) d x\right) f^{\prime}(t) d t .
$$

Remark 2. For the weighted Čebyšev functional defined by

$T(f, g, p)=\int_{a}^{b} p(x) d x \int_{a}^{b} p(x) f(x) g(x) d x-\int_{a}^{b} p(x) f(x) d x \int_{a}^{b} p(x) g(x) d x$

the following representation identity has been proved by J. Pečarić in [6]:

$T(f, g, p)=\int_{a}^{b} \bar{P}(x) \int_{a}^{x} P(t) d g(t) d f(x)+\int_{a}^{b} P(x) \int_{x}^{b} \bar{P}(t) d g(t) d f(x)$

where $f, g:[a, b] \rightarrow \mathbb{R}$ are two differentiable functions on $[a, b]$ and $p:$ $[a, b] \rightarrow \mathbb{R}$ integrable, $P(x)=\int_{a}^{x} p(t) d t, \bar{P}(x)=\int_{x}^{b} p(t) d t$, for which $0 \leq P(x) \leq P(b), \forall x \in[a, b]$ holds.

If we rewrite this identity for $p \equiv w$ and $f, g:[a, b] \rightarrow \mathbb{R}$ absolutely continuous on $[a, b]$, we obtain (7).

For the uniform normalized weight function $w(t)=\frac{1}{b-a}, t \in[a, b]$, identity (7) reduce to the Dragomir's result (2) from the introduction.

Next, we can state the following integral representation for perturbed weighted Čebyšev functional $T_{w}(f-\mu e, g-\nu e)$ when $\mu, \nu \in \mathbb{R}$ and $e(t)=$ $t, t \in[a, b]$.

Theorem 4. If $f, g:[a, b] \rightarrow \mathbb{R}$ are absolutely continuous on $[a, b], w, W$ such as in Lemma 1 and $e:[a, b] \rightarrow \mathbb{R}, e(t)=t$, we have

$$
\begin{aligned}
T_{w}(f, g)= & \mu T_{w}(e, g)+\nu T_{w}(f, e)-\mu \nu T_{w}(e, e) \\
& +\int_{a}^{b} \int_{a}^{b} K_{w}(x, t)\left(f^{\prime}(t)-\mu\right)\left(g^{\prime}(x)-\nu\right) d x d t
\end{aligned}
$$

for any $\mu, \nu \in \mathbb{R}$. 
Proof. By using identity (7) and utilizing the linearity property of $T_{w}(f, g)$ in each argument, we have

$$
T_{w}(f-\mu e, g-\nu e)=T_{w}(f, g)-\mu T_{w}(e, g)-\nu T_{w}(f, e)+\mu \nu T_{w}(e, e)
$$

for any $\mu, \nu \in \mathbb{R}$.

Remark 3. For the uniform normalized weight function $w(t)=\frac{1}{b-a}, t \in$ $[a, b]$, the result from Theorem 4 reduces to the next result from [2].

\section{BOUNDS FOR PERTURBED WEIGHTED ČEBYŠEV FUNCTIONAL}

In the next Theorem, utilizing the representation (6) we obtain the bounds for perturbed weighted Cebyšev functional $T_{w}(f-\mu e, g)$ when $\mu \in \mathbb{R}$ in terms of Lebesgue norms of $g, w$ and $f^{\prime}$.

Theorem 5. Assume that $g:[a, b] \rightarrow \mathbb{R}$ is Lebesgue integrable function on $[a, b]$ and $f:[a, b] \rightarrow \mathbb{R}$ is absolutely continuous on $[a, b], w:[a, b] \rightarrow[0, \infty\rangle$ is some Lebesgue integrable normalized weight function and $e:[a, b] \rightarrow \mathbb{R}$, $e(t)=t$. Then for $p, q>1$ such that $1 / p+1 / q=1$ and any $\mu \in \mathbb{R}$ we have

$$
\begin{aligned}
& \left|T_{w}(f, g)-\mu T_{w}(e, g)\right| \\
& \leq\left\{\begin{array}{c}
I_{w}^{1}\left\|f^{\prime}-\mu\right\|_{\infty} \inf _{\lambda \in \mathbb{R}}\|w(g-\lambda)\|_{\infty}, \quad \text { if } f^{\prime}, g, w \in L_{\infty}[a, b], \\
I_{w}^{q}\left\|f^{\prime}-\mu\right\|_{p} \inf _{\lambda \in \mathbb{R}}\|w(g-\lambda)\|_{p}, \\
\left\|f^{\prime}-\mu\right\|_{1} \inf _{\lambda \in \mathbb{R}}\|w(g-\lambda)\|_{1}
\end{array}\right.
\end{aligned}
$$

where

$$
I_{w}^{q}=\left(\int_{a}^{b} \int_{a}^{b}\left|P_{w}(x, t)\right|^{q} d x d t\right)^{\frac{1}{q}} .
$$

Proof. From (6) we have

$$
\begin{aligned}
& \left|T_{w}(f, g)-\mu T_{w}(e, g)\right|=\left|\int_{a}^{b} \int_{a}^{b} w(x) P_{w}(x, t)(g(x)-\lambda)\left(f^{\prime}(t)-\mu\right) d x d t\right| \\
& \leq \int_{a}^{b} \int_{a}^{b} w(x)\left|P_{w}(x, t)\right||g(x)-\lambda|\left|f^{\prime}(t)-\mu\right| d x d t \\
& \leq\left\|f^{\prime}-\mu\right\|_{\infty}\|w(g-\lambda)\|_{\infty} \int_{a}^{b} \int_{a}^{b}\left|P_{w}(x, t)\right| d x d t .
\end{aligned}
$$

Taking the infimum over $\lambda \in \mathbb{R}$ provides the first inequality.

Applying the Hölder inequality for double integrals we have

$$
\int_{a}^{b} \int_{a}^{b} w(x)\left|P_{w}(x, t)\right||g(x)-\lambda|\left|f^{\prime}(t)-\mu\right| d x d t
$$


12 ANDREA AGLIĆ ALJINOVIĆ, JOSIP PEČARIĆ, AND SANJA TIPURIĆ-SPUŽEVIĆ

$$
\begin{aligned}
& \leq\left(\int_{a}^{b} \int_{a}^{b}\left|P_{w}(x, t)\right|^{q} d x d t\right)^{\frac{1}{q}}\left(\int_{a}^{b} \int_{a}^{b}|w(x)(g(x)-\lambda)|^{p}\left|f^{\prime}(t)-\mu\right|^{p} d x d t\right)^{\frac{1}{p}} \\
& =\left(\int_{a}^{b} \int_{a}^{b}\left|P_{w}(x, t)\right|^{q} d x d t\right)^{\frac{1}{q}}\left(\int_{a}^{b}\left|f^{\prime}(t)-\mu\right|^{p} d t \cdot \int_{a}^{b}|w(x)(g(x)-\lambda)|^{p} d x\right)^{\frac{1}{p}} \\
& =I_{w}^{q}\left\|f^{\prime}-\mu\right\|_{p}\|w(g-\lambda)\|_{p} .
\end{aligned}
$$

Taking the infimum over $\lambda \in \mathbb{R}$ provides the second inequality.

For the last part, since $0 \leq W(t) \leq 1, t \in[a, b]$ we have

$$
\sup _{(x, t) \in[a, b]^{2}}\left|P_{w}(x, t)\right|=1
$$

and

$$
\begin{aligned}
& \int_{a}^{b} \int_{a}^{b} w(x)\left|P_{w}(x, t)\right||g(x)-\lambda|\left|f^{\prime}(t)-\mu\right| d x d t \\
& \leq\left\|P_{w}(x, t)\right\|_{\infty} \int_{a}^{b} \int_{a}^{b} w(x)|g(x)-\lambda|\left|f^{\prime}(t)-\mu\right| d x d t \\
& \leq\left\|P_{w}(x, t)\right\|_{\infty}\|w(g-\lambda)\|_{1}\left\|f^{\prime}-\mu\right\|_{1}=\|w(g-\lambda)\|_{1}\left\|f^{\prime}-\mu\right\|_{1} .
\end{aligned}
$$

again, taking the infimum over $\lambda \in \mathbb{R}$ completes the proof.

Remark 4. If we take $w(t)=\frac{1}{b-a}, t \in[a, b]$, we have

$$
\begin{aligned}
& \int_{a}^{b} \int_{a}^{b}\left|P_{w}(x, t)\right|^{q} d x d t=\int_{a}^{b} \int_{a}^{b}|P(x, t)|^{q} d x d t \\
& =\frac{1}{(b-a)^{q}} \int_{a}^{b}\left(\int_{a}^{x}(t-a)^{q} d t+\int_{x}^{b}(b-t)^{q} d t\right) d x=\frac{2(b-a)^{2}}{(q+1)(q+2)}
\end{aligned}
$$

and

$$
\begin{gathered}
I_{w}^{q}=\left(\frac{2(b-a)^{2}}{(q+1)(q+2)}\right)^{\frac{1}{q}} \\
\|w(g-\lambda)\|_{p}=\frac{1}{b-a}\|g-\lambda\|_{p}
\end{gathered}
$$

Thus, for the uniform normalized weight function (10) reduces to the inequality from the Theorem 1.

Corollary 1. Suppose that all assumptions of Theorem 5 hold. Additionally, if $-\infty<m \leq g(x) \leq M<\infty$ for a.e. $x \in[a, b]$ then for any $\mu \in \mathbb{R}$ we have

$$
\left|T_{w}(f, g)-\mu T_{w}(e, g)\right|
$$




$$
\leq\left\{\begin{array}{cl}
\frac{1}{2} I_{w}^{1}(M-m)\|w\|_{\infty}\left\|f^{\prime}-\mu\right\|_{\infty}, & \text { if } f^{\prime} \in L_{\infty}[a, b], \\
\frac{1}{2} I_{w}^{q}(M-m)(b-a)^{\frac{1}{p}}\|w\|_{\infty}\left\|f^{\prime}-\mu\right\|_{p}, & \text { if } f^{\prime} \in L_{p}[a, b], \\
\frac{1}{2}(M-m)(b-a)\|w\|_{\infty}\left\|f^{\prime}-\mu\right\|_{1} . &
\end{array}\right.
$$

Proof. If $-\infty<m \leq g(x) \leq M<\infty$ for a.e. $x \in[a, b]$, then

$$
\begin{aligned}
& \inf _{\lambda \in \mathbb{R}}\|w(g-\lambda)\|_{\infty} \leq\left\|w\left(g-\frac{m+M}{2}\right)\right\|_{\infty} \\
& \leq\|w\|_{\infty}\left\|\left(g-\frac{m+M}{2}\right)\right\|_{\infty} \leq\|w\|_{\infty} \frac{1}{2}(M-m)
\end{aligned}
$$

and for $p \geq 1$

$$
\begin{aligned}
& \inf _{\lambda \in \mathbb{R}}\|w(g-\lambda)\|_{p} \leq\left\|w\left(g-\frac{m+M}{2}\right)\right\|_{p} \\
& \leq\|w\|_{\infty}\left\|\left(g-\frac{m+M}{2}\right)\right\|_{p}=\|w\|_{\infty} \frac{1}{2}(M-m)(b-a)^{\frac{1}{p}} .
\end{aligned}
$$

Applying (10) the proof follows.

Corollary 2. Suppose that all assumptions of Theorem 5 hold. Additionally, if $-\infty<\gamma \leq f^{\prime}(t) \leq \Gamma<\infty$ for a.e. $t \in[a, b]$ then we have

$$
\begin{aligned}
& \left|T_{w}(f, g)-\frac{\gamma+\Gamma}{2} T_{w}(e, g)\right| \\
& \leq\left\{\begin{array}{c}
\frac{1}{2} I_{w}^{1}(\Gamma-\gamma) \inf _{\lambda \in \mathbb{R}}\|w(g-\lambda)\|_{\infty}, \\
\frac{1}{2} I_{w}^{q}(\Gamma-\gamma)(b-a)^{\frac{1}{p}} \inf _{\lambda \in \mathbb{R}}\|w(g-\lambda)\|_{p}, \quad \text { if } g \in L_{\infty}[a, b], \\
\frac{1}{2}(\Gamma-\gamma)(b-a) \inf _{\lambda \in \mathbb{R}}\|w(g-\lambda)\|_{1} .
\end{array}\right.
\end{aligned}
$$

Proof. If $-\infty<\gamma \leq f^{\prime}(t) \leq \Gamma<\infty$ for a.e. $t \in[a, b]$ then

$$
\left\|f^{\prime}-\frac{\gamma+\Gamma}{2}\right\|_{\infty} \leq \frac{1}{2}(\Gamma-\gamma)
$$

and for $p \geq 1$

$$
\left\|f^{\prime}-\frac{\gamma+\Gamma}{2}\right\|_{p} \leq \frac{1}{2}(\Gamma-\gamma)(b-a)^{\frac{1}{p}} .
$$

Applying (10) the proof follows.

In the next Theorem, utilizing the representation (9) we obtain the bounds for perturbed weighted Čebyšev functional $T_{w}(f, g)-\mu T_{w}(e, g)-$ $\nu T_{w}(f, e)$ when $\mu, \nu \in \mathbb{R}$ in terms of Lebesgue norms of $f^{\prime}$ and $g^{\prime}$. 
14 ANDREA AGLIĆ ALJINOVIĆ, JOSIP PEČARIĆ, AND SANJA TIPURIĆ-SPUŽEVIĆ

Theorem 6. If $f, g:[a, b] \rightarrow \mathbb{R}$ are absolutely continuous on $[a, b], w:$ $[a, b] \rightarrow[0, \infty\rangle$ is some normalized weight function and $e:[a, b] \rightarrow \mathbb{R}$, $e(t)=t$. Then for $p, q>1$ such that $1 / p+1 / q=1$ and any $\mu, \nu \in \mathbb{R}$ we have

$$
\begin{aligned}
& \left|T_{w}(f, g)-\mu T_{w}(e, g)-\nu T_{w}(f, e)+\mu \nu T_{w}(e, e)\right| \\
& \leq\left\{\begin{array}{c}
J_{w}^{1}\left\|f^{\prime}-\mu\right\|_{\infty}\left\|\left(g^{\prime}-\nu\right)\right\|_{\infty}, \quad \text { if } f^{\prime}, g^{\prime} \in L_{\infty}[a, b], \\
J_{w}^{q}\left\|f^{\prime}-\mu\right\|_{p}\left\|g^{\prime}-\nu\right\|_{p}, \\
\frac{1}{4}\left\|f^{\prime}-\mu\right\|_{1}\left\|g^{\prime}-\nu\right\|_{1}
\end{array}\right.
\end{aligned}
$$

where

$$
J_{w}^{q}=\left(\int_{a}^{b} \int_{a}^{b} K_{w}(x, t)^{q} d x d t\right)^{\frac{1}{q}} .
$$

Proof. From (9) we have

$$
\begin{aligned}
& \left|T_{w}(f, g)-\mu T_{w}(e, g)-\nu T_{w}(f, e)+\mu \nu T_{w}(e, e)\right| \\
& \leq \int_{a}^{b} \int_{a}^{b} K_{w}(x, t)\left|f^{\prime}(t)-\mu\right|\left|g^{\prime}(x)-\nu\right| d x d t \\
& \leq\left\|f^{\prime}-\mu\right\|_{\infty}\left\|\left(g^{\prime}-\nu\right)\right\|_{\infty} \int_{a}^{b} \int_{a}^{b} K_{w}(x, t) d x d t .
\end{aligned}
$$

Applying the Hölder inequality for double integrals we have

$$
\begin{aligned}
& \int_{a}^{b} \int_{a}^{b} K_{w}(x, t)\left|f^{\prime}(t)-\mu\right|\left|g^{\prime}(x)-\nu\right| d x d t \\
& \leq\left(\int_{a}^{b} \int_{a}^{b} K_{w}(x, t)^{q} d x d t\right)^{\frac{1}{q}}\left(\int_{a}^{b} \int_{a}^{b}\left|g^{\prime}(x)-\nu\right|^{p}\left|f^{\prime}(t)-\mu\right|^{p} d x d t\right)^{\frac{1}{p}} \\
& =J_{w}^{q}\left\|f^{\prime}-\mu\right\|_{p}\left\|g^{\prime}-\nu\right\|_{p} .
\end{aligned}
$$

For the last part, we have for $a \leq t \leq x \leq b$, that

$$
K_{w}(x, t)=W(t)(1-W(x)) \leq W(t)(1-W(t))
$$

since $W(t)=\int_{a}^{t} w(x) d x \leq W(x)$ and similarly for $a \leq x<t \leq b$

$$
K_{w}(x, t)=(1-W(t)) W(x) \leq W(t)(1-W(t)) .
$$

We can deduce that

$$
K_{w}(x, t) \leq \frac{1}{4}, \quad x, t \in[a, b]
$$

since $0 \leq W(t) \leq 1, t \in[a, b]$. Finally

$$
\int_{a}^{b} \int_{a}^{b} K_{w}(x, t)\left|f^{\prime}(t)-\mu\right|\left|g^{\prime}(x)-\nu\right| d x d t
$$




$$
\begin{aligned}
& \leq\left\|K_{w}(x, t)\right\|_{\infty} \int_{a}^{b} \int_{a}^{b}\left|f^{\prime}(t)-\mu\right|\left|g^{\prime}(x)-\nu\right| d x d t \\
& =\frac{1}{4}\left\|f^{\prime}-\mu\right\|_{1}\left\|g^{\prime}-\nu\right\|_{1} .
\end{aligned}
$$

Remark 5. If we take $w(t)=\frac{1}{b-a}, t \in[a, b]$, we have

$$
\begin{aligned}
& \int_{a}^{b} \int_{a}^{b} K_{w}(x, t)^{q} d x d t=\int_{a}^{b} \int_{a}^{b} K(x, t)^{q} d x d t \\
& =\frac{1}{(b-a)^{2 q}} \int_{a}^{b}\left(\int_{a}^{x}(t-a)^{q}(b-x)^{q} d t+\int_{x}^{b}(b-t)^{q}(x-a)^{q} d t\right) d x \\
& =\frac{1}{(q+1)(b-a)^{2 q}} \int_{a}^{b}\left((x-a)^{q+1}(b-x)^{q}+(b-x)^{q+1}(x-a)^{q}\right) d x
\end{aligned}
$$

The Beta function is defined by

$$
B(\alpha, \beta)=\int_{0}^{1} t^{\alpha-1}(1-t)^{\beta-1} d t \quad \alpha, \beta>0
$$

so by substitution $x-a=s(b-a)$ we get

$$
\begin{aligned}
& \int_{a}^{b}(x-a)^{q+1}(b-x)^{q} d x=(b-a)^{2 q+2} \int_{0}^{1} s^{q+1}(1-s)^{q} d s \\
& =(b-a)^{2 q+2} B(q+2, q+1)
\end{aligned}
$$

and

$$
\begin{aligned}
& \int_{a}^{b}(b-x)^{q+1}(x-a)^{q} d x=(b-a)^{2 q+2} \int_{0}^{1} s^{q}(1-s)^{q+1} d s \\
& =(b-a)^{2 q+2} B(q+1, q+2) .
\end{aligned}
$$

Since $B(q+1, q+2)=\frac{1}{2} B(q+1, q+1)$ we get

$$
\int_{a}^{b} \int_{a}^{b} K(x, t)^{q} d x d t=\frac{(b-a)^{2}}{(q+1)} B(q+1, q+1) .
$$

Thus, for the uniform normalized weight function (11) reduces to the inequality from the Theorem 2.

Corollary 3. Suppose that all assumptions of Theorem 6 hold. Then we have

$$
\left|T_{w}(f, g)\right| \leq\left\{\begin{array}{cl}
J_{w}^{1}\left\|f^{\prime}\right\|_{\infty}\left\|g^{\prime}\right\|_{\infty}, & \text { if } f^{\prime}, g^{\prime} \in L_{\infty}[a, b], \\
J_{w}^{q}\left\|f^{\prime}\right\|_{p}\left\|g^{\prime}\right\|_{p}, & \text { if } f^{\prime}, g^{\prime} \in L_{p}[a, b], \\
\frac{1}{4}\left\|f^{\prime}\right\|_{1}\left\|g^{\prime}\right\|_{1} . &
\end{array}\right.
$$


16 ANDREA AGLIĆ ALJINOVIĆ, JOSIP PEČARIĆ, AND SANJA TIPURIĆ-SPUŽEVIĆ

Proof. Applying (11) with $\mu=\nu=0$ the proof follows.

Remark 6. Taking $w(t)=\frac{1}{b-a}, t \in[a, b]$, in the last corollary we have

$$
|T(f, g)| \leq\left\{\begin{array}{cl}
\frac{1}{12}(b-a)^{2}\left\|f^{\prime}\right\|_{\infty}\left\|g^{\prime}\right\|_{\infty}, & \text { if } f^{\prime}, g^{\prime} \in L_{\infty}[a, b], \\
\left(\frac{(b-a)^{2}}{(q+1)} B(q+1, q+1)\right)^{\frac{1}{q}}\left\|f^{\prime}\right\|_{p}\left\|g^{\prime}\right\|_{p}, & \text { if } f^{\prime}, g^{\prime} \in L_{p}[a, b], \\
\frac{1}{4}\left\|f^{\prime}\right\|_{1}\left\|g^{\prime}\right\|_{1} . &
\end{array}\right.
$$

Notice that the first inequality is exactly the Čebyšev inequality from 1882. and the other two were obtained in [2].

Corollary 4. Suppose that all assumptions of Theorem 6 hold. Additionally, if we assume that $-\infty<\gamma<f^{\prime}(t) \leq \Gamma<\infty$ and $-\infty<\phi<g^{\prime}(t) \leq$ $\Phi<\infty$ for a.e. $t \in[a, b]$, then we have the following inequality

$$
\begin{aligned}
& \left|T_{w}(f, g)-\frac{\gamma+\Gamma}{2} \cdot T_{w}(e, g)-\frac{\phi+\Phi}{2} \cdot T_{w}(f, e)+\frac{(\gamma+\Gamma)(\phi+\Phi)}{4} T_{w}(e, e)\right| \\
& \leq\left\{\begin{array}{cl}
J_{w}^{1} \cdot \frac{1}{4}(\Gamma-\gamma)(\Phi-\phi), & \text { if } f^{\prime}, g^{\prime} \in L_{\infty}[a, b], \\
J_{w}^{q} \cdot \frac{1}{4}(\Gamma-\gamma)(\Phi-\phi)(b-a)^{\frac{2}{p}}, & \text { if } f^{\prime}, g^{\prime} \in L_{p}[a, b], \\
\frac{1}{4}(\Gamma-\gamma)(\Phi-\phi)(b-a)^{2} . &
\end{array}\right.
\end{aligned}
$$

Proof. If $-\infty<\gamma \leq f^{\prime}(t) \leq \Gamma<\infty$ and $-\infty<\phi<g^{\prime}(t) \leq \Phi<\infty$ for a.e. $t \in[a, b]$ then

$$
\begin{aligned}
& \left\|f^{\prime}-\frac{\gamma+\Gamma}{2}\right\|_{\infty} \leq \frac{1}{2}(\Gamma-\gamma), \\
& \left\|f^{\prime}-\frac{\phi+\Phi}{2}\right\|_{\infty} \leq \frac{1}{2}(\Phi-\phi)
\end{aligned}
$$

and for $p \geq 1$

$$
\begin{aligned}
& \left\|f^{\prime}-\frac{\gamma+\Gamma}{2}\right\|_{p} \leq \frac{1}{2}(\Gamma-\gamma)(b-a)^{\frac{1}{p}}, \\
& \left\|f^{\prime}-\frac{\phi+\Phi}{2}\right\|_{p} \leq \frac{1}{2}(\Gamma-\gamma)(b-a)^{\frac{1}{p}} .
\end{aligned}
$$

Applying (11) the proof follows. 
Remark 7. Taking $w(t)=\frac{1}{b-a}, t \in[a, b]$, in the last corollary we have

$$
\begin{aligned}
& \left|T(f, g)-\frac{\gamma+\Gamma}{2} \cdot T(e, g)-\frac{\phi+\Phi}{2} \cdot T(f, e)+\frac{(\gamma+\Gamma)(\phi+\Phi)}{4} T_{w}(e, e)\right| \\
& \leq\left\{\begin{array}{cc}
\frac{1}{48}(b-a)^{2}(\Gamma-\gamma)(\Phi-\phi), & \text { if } f^{\prime}, g^{\prime} \in L_{\infty}[a, b], \\
\left(\frac{1}{(q+1)} B(q+1, q+1)\right)^{\frac{1}{q}} \cdot \frac{1}{4}(\Gamma-\gamma)(\Phi-\phi)(b-a)^{2}, & \text { if } f^{\prime}, g^{\prime} \in L_{p}[a, b], \\
\frac{1}{4}(\Gamma-\gamma)(\Phi-\phi)(b-a)^{2} . &
\end{array}\right.
\end{aligned}
$$

Acknowledgement. This research was supported by the Croatian Ministry of Science, Education, and Sports, under Research Grants 0361170889-1054 (first author) and 117-1170889-0888 (second author).

\section{REFERENCES}

[1] P. L. Čebyšev: Sur les expressions approximatives des integrales definies par les autres prises entre les memes limites, Proc. Math. Soc. Charkov2 (1882) 93-98.

[2] S. S. Dragomir: Bounds for some perturbed Čebyšev functionals, JIPAM, Vol 9 (2008), Issue 3, Article 64.

[3] G. Grüss, Über das Maximum des absoluten Betrages von $\frac{1}{b-a} \int_{a}^{b} f(x) g(x) d x-$ $\frac{1}{(b-a)^{2}} \int_{a}^{b} f(x) d x \int_{a}^{b} g(x) d x$, Math. Z., 39 (1935), 215-226.

[4] D. S. Mitrinović, J. E. Pečarić, and A. M. Fink, Inequalities for functions and their Integrals and Derivatives, Kluwer Academic Publishers, Dordrecht, 1994.

[5] J. Pečarić, On the Čebyšev inequality, Bul. Inst. Politehn. Timisoara 25 (39) (1980), 5-9.

[6] J. Pečarić, On the Ostrowski Generalization of Čebyšev Inequality, Journal Of Mathematical Analysis and Applications, Vol. 102, No. 2, (1984), 392-400.

[7] N.J. Sonin, O nekotoryh neravnenstvah, otnosjascihsja $k$ opredelennym intagralam, Zap. Imp. Akad. Nauk po fiziko-matem. otd. t. 6 (1898), 1-54. 
18 ANDREA AGLIĆ ALJINOVIĆ, JOSIP PEČARIĆ, AND SANJA TIPURIĆ-SPUŽEVIĆ

\title{
ИДЕНТИТЕТИ ОД ТИП НА СОНИН И ПРИМЕНА
}

\author{
Андреа Аглиќ Аљиновиќ, Јосип Печариќ, Сања Типуриќ-Спужевиќ
}

\section{P е зи и е}

Направени се некои генерализации на идентитети за пертурбирани Чебишеви функционали користејќи го идентитетот на Сонин. Тие се искористени за добивање на нови граници за пертурбирани Чебишеви функционали. Во специјален случај се редуцираат до неравенства од типот на Грос.

Department of applied mathematics, Faculty of Electrical Engineering and Computing, University of Zagreb, Unska 3, 10000 Zagreb, Croatia

E-mail address: andrea.aglic@fer.hr

Faculty of textile technology, University of Zagreb, Pierottijeva 6, 10000 Zagreb, Croatia

E-mail address: pecaric@hazu.hr

Faculty of Science and Education, University of Mostar, Matice hrvatske BB, 88000 Mostar, Bosnia And Herzegovina

E-mail address: sanja.spuzevic@tel.net.ba 